DOI 10.5281 /zenodo. 1244816

\title{
Detecting Radicalisation in Communities: The Role of Multi-Agency Partnership and the Power of Local Information
}

\author{
Sue Roberts \\ Senior Lecturer, University of Portsmouth, UK \\ sue.roberts@port.ac.uk
}

\begin{abstract}
Following the 2017 UK terrorist attacks by extremist religious individuals, it is notable that politicians and individual commentators remarked on the pressing need for local partnership working in England (BBC question time, 5 June 2017; Faith Matters 2017; Brendan Cox 19 June 2017). For it is by this means, people working together in a community, that local information and intelligence can be accessed, especially relating to emerging radicalisation. The early warning signs that could lead to active terrorism of the kind witnessed in the 2017 attacks (UNISON 2016) are being missed, and there are reasons why.

This paper looks at why local information and multi-agency partnership are important to policing and community safety in the context of concerns about radicalisation and extremism, reviewing the policy changes, and their effects in partnership arrangements that have occurred in the UK since 2010. The paper goes on to present findings about the crucial significance of local partnership working in detecting radicalisation and some of the challenges faced by professionals now. The third part of the paper considers the question of how relevant agencies can monitor ongoing extremism and terrorism in communities through local intelligence gleaned through partnership working and other means.

KEYWORDS: extremism, terrorism, partnerships, multi-agency, communities, collaboration, governance
\end{abstract}




\section{Why partnership matters}

The Faith Matters Group, a UK-based multi-faith organisation, wrote an open letter to the Prime Minister, Theresa May in 2017 saying

"The only way forward is through multi-level engagement and dialogue, irrespective of political differences. Her Majesty's Government is also our Government and we firmly believe that dialogue and partnership are the best ways to counter extremism."

This sentiment was echoed in BBC television's Question Time prior to the 2017 general election by Nicola Sturgeon, first Minister of Scotland (BBC 2017) and by Brendan Cox, the husband of murdered English MP, Jo Cox, on the BBC news on 19 June 2017. Both the Scottish first minister and Brendan Cox emphasised the need for communities to work together and for statutory agencies to involve themselves in partnership with them. This, it was suggested, will help to identify early warning signs and concerns in communities about individuals and groups that could be at risk of extremism or terrorist activity. In light of these concerns, it is important to focus attention on some of the key policy changes that have contributed to a decline in local partnership working and community cohesion, whilst trying to answer the questions raised.

There is evidence in the research for this paper that partnership and joint working at local level can be a significant contributor in the move towards tackling religious extremism where it appears to germinate in communities. We must ask why, after these latest terrorist incidents, do ordinary people appear to be calling for a return to local partnership working rather than encouraging us to build on existing partnerships? What could have happened to community links with statutory and non-statutory bodies that we are now asking ourselves searching questions about how religious extremism and terrorism goes undetected by those that could, in theory, respond? Critically, why does there now seem to be a gap in this local intelligence? This paper offers some possible responses to these questions about our connectedness to local people.

Whatever the dearth in partnership working at local level, it behoves us in light of these recent terrorist attacks, to question the ongoing role of civic society in helping to prevent radicalisation and terrorism. If we are to respond as a "joined up society" to the tragedies created by terrorism, an exploration of the current position with regard to local, community-based partnership in England is clearly important and timely. 


\section{The roots of multi-agency partnership working}

Multi-agency partnership as a concept is not new. Most local authorities in England have worked closely with various agencies and communities over the years, but in the early days of the 1997 Blair government in the UK, multi-agency partnership became a key operational mechanism for a more "joined up" form of government and localism (Ling 2002, 616; Pollitt 2003). This was intended to encourage closer working between central and local governments to further the notion of localism, encourage greater interaction between stakeholders at local level to support policy and make good use of resources.

The Children Act, 1989 (Great Britain 1989) established the statutory framework for inter-agency collaboration in the UK, setting up the foundations for co-operation between different organisations, stakeholders and ordinary people in a given locality (Cheminais 2008, 1). Multi agency partnerships (MAPs) became a statutory requirement for local government in England with the Crime and Disorder Act 1998 (Great Britain 1998) which established Crime and Disorder Reduction Partnerships (CDRPs, now Community Safety Partnerships or CSPs) in localities across the country. Local Strategic Partnerships (LSPs) followed in 2000 with the Local Government Act (Great Britain 2000) which were similarly constituted but with a wider brief across communities. The CSPs still have a statutory remit, and therefore retain validity in the wider picture of community safety. The LSPs, however, do not. That does not mean to say that the LSPs are in any sense less valid. Many have changed to become community partnerships, delivering good quality community partnership working, or have been absorbed into the CSP (Roberts 2016,1).

Multi agency partnerships such as the LSPs and CSPs are characterised by their breadth and variety of membership. This was set out in the legislation and statutory instruments that initiated them in the first place (Great Britain 1989; Great Britain 2000; DETR 09, 2001). Members usually include Police, Fire and Rescue Services, Local Authorities, Faith Groups, NHS, Voluntary sector, Education, Probation, representatives, community leaders, Social and Caring services, those dealing with domestic abuse and many others. The idea was, and still is, that all sections of the community should be represented, providing a forum for the discussion of relevant local issues within a given area, which usually tends to be urban-based, even if those members of the partnership also represent more rural areas. The governance for these partnerships, although set out at national level, is intended to reflect the local area. 
The practice of running public services locally within a geographically close area fits with the notion of corporatist governance (Pierre 2011,49). Corporatist Governance as described by Pierre (2011) focuses on multi-agency public service delivery within an urban geographical area and, significantly, is characterised by a more "distributive" (p. 50) form of network governance. This means that governance is shared among members as with CSPs and LSPs. Co-operation and joint working are typical of a corporatist governance environment, which includes ordinary members of the public with an interest in the area. Most significant of all is the encouragement of "public discourse on matters of public concern" (p. 51). Here at the most local of levels, important information can be shared, not just between statutory agencies such as the police and local authorities, but with all partners, including those members of the public who are involved. This approach is typical of both the CSPs and the LSPs and is a recognised form of "partnership paradigm" (Crawford in Delpeuch and Ross 2016 , 3) for community and knowledge-based policing.

Any changes to the process of corporatist governance in a given area will weaken the chain of local information, as with the removal of the Police Community Support Officers (PCSOs) in some areas (Greig-Midlane 2014; Loveday 2017a; Loveday 2017b) and the demise of local partnerships such as the LSPs and the distancing of the CSPs from the Police and Crime Commisioners (Loveday 2013). The loss of the PCSOs is a very troubling issue in the fragmentation of local information from communities and appears to represent a bid to preserve the establishment posts of full police officers (Greig-Midlane 2014, 7; UNISON 2016). In light of the comments made by politicians and other commentators referred to previously, Andy Stenning, (2016) stated in the UNISON interview cited above

"If you look at counter terrorism, PCSOs are the eyes and ears of the counter terrorism branch, they are engaging with all communities, and learning about what's going on. They have what we call 'local intelligence' that in crime situations leads us to offenders, and in terrorist situations to the terrorists."

This is supported by the research for this paper. One participant from Surrey Police (Interview 1) affirmed that the intelligence from PCSOs gives police officers vital local knowledge about where problems are likely to occur, who could be involved and where to direct precious, diminishing police resources. In times of extreme stress in public sector spending, this information saves both time and resources. The removal of the PCSOs (Greig-Midlane 2014, 7) in forces across the country weakens a central link in the chain of local knowledge and by extension, the ability for the police and other agencies to detect emerging threats such as extremism and terrorism. 


\section{Changes in governance and partnership arrangements}

Since 2010 and the introduction of the Localism Act 2011, (Great Britain 2011) which dismantled the power of Local Strategic Partnerships (LSPs) in England by removing the Local Area Agreements (Rees, Mullins and Bovaird 2012, 5) local joint working between agencies has become more fragmented. Added to this, the Community Safety Partnerships have seen their role confused and in some cases sidelined by the introduction of the Police and Crime Commissioners (PCCs) (Crawford in Delpeuch and Ross 2016). Loveday (2013) warned of this, pointing out that the PCCs could affect the Community Safety Partnerships (CSPs) negatively. There is no statutory imperative to compel the PCCs to work with CSPs and the concern that he mentions in this paper emanating from CSPs about the rather flaccid responsibility by PCCs to "monitor" the CSPs appears to cast the PCCs in a more remote role. The research for this paper supports that perception in that respondents report a sense of separation and remoteness from PCCs, and indeed one respondent (Interview 3) from the offices of a PCC confirmed that the role focuses more on the "national, than the local picture". Loveday's (2013) paper goes on to discuss the benefits of local multi agency partnership, established under the Crime and Disorder Act 1998 (Great Britain1998) in which agencies were required to work together to tackle local issues. CSPs are still functioning in most areas, and continue to deliver the multi-agency work that connects local communities with statutory bodies, but there is concern over the future under the aegis of the PCCs and the distancing of the relationship between the two of them (Crawford in Delpeuch and Ross 2016). The remoteness in the relationship between some PCCs and CSPs represents a dislocation from the local to the national picture and begs the question: how can the kind of local intelligence that could help detect radicalisation and nascent terrorist activity be effectively shared with those in a national policy-influencing position without strong connections and close working between the two? This is taking place within an environment of diminishing police resources, (Disney and Simpson 2017). In this financial climate, there are anxieties that the police may need to divert already strained resources towards tackling terrorism, which may leave other core services vulnerable (interviews 1,2 and 5 ). This situation is something of a "Catch22". Focusing large scale resources on terrorism may drain the very local resources that could help detect it. Notwithstanding this difficult situation and given that tackling terrorism is a key priority, the connections to vital local intelligence, where terrorism can germinate through radicalisation, are more important than ever. Terrorism is not openly discussed on a national stage by those who are plotting it, but it does appear to begin covertly in local communities. 
It should be remembered that most local partnerships and public services are operating in an environment in which rapidly contracting resources dominate the agenda for public services. No respite appears to be forthcoming, and further cuts to public spending are planned (LGA 2017). Meanwhile the research for this paper has shown that the relationships between some CSPs and PCCs continue to be uncertain and a cause for concern, especially among community safety practitioners in local councils. (Crawford in Delpuech and Ross 2016, 148). This represents a difficult operating environment in which local information can be easily shared.

\section{Political and policy changes}

The policy changes and revisions to policy since the advent of the UK Coalition Government in 2010 and the Conservative Government in 2015 have all led in a particular direction. The Coalition, then Conservative government policy of Austerity was initiated as a political response to part of a global crisis precipitated by the failure of the sub-prime mortgage market in the US and the increase in risky lending activities on the part of some banks and financial institutions. The reaction to this by the UK Coalition Government in 2010 was to launch a programme of Austerity to tackle a national financial deficit exacerbated by this crisis. Austerity was undertaken in the British public sector as an approach to reducing the size of the state and cutting public spending whilst enlarging the role of the private sector in the delivery of public services (Sawyer 2011, 4).

The brunt of the cuts to public spending under Austerity were borne by local government in the first instance (JRF 2015) and by major services such as the NHS and the Police. The drive to reduce public spending was announced resulting in a projected end to direct government grant funding to local authorities in England by 2020. This news produced the now famous Barnet council "graph of doom" showing the demands on local authorities to provide adult social care and children's services alone and the amount expected in government grants through to 2020 when central government funding through the Revenue Support Grant would drastically reduce. 


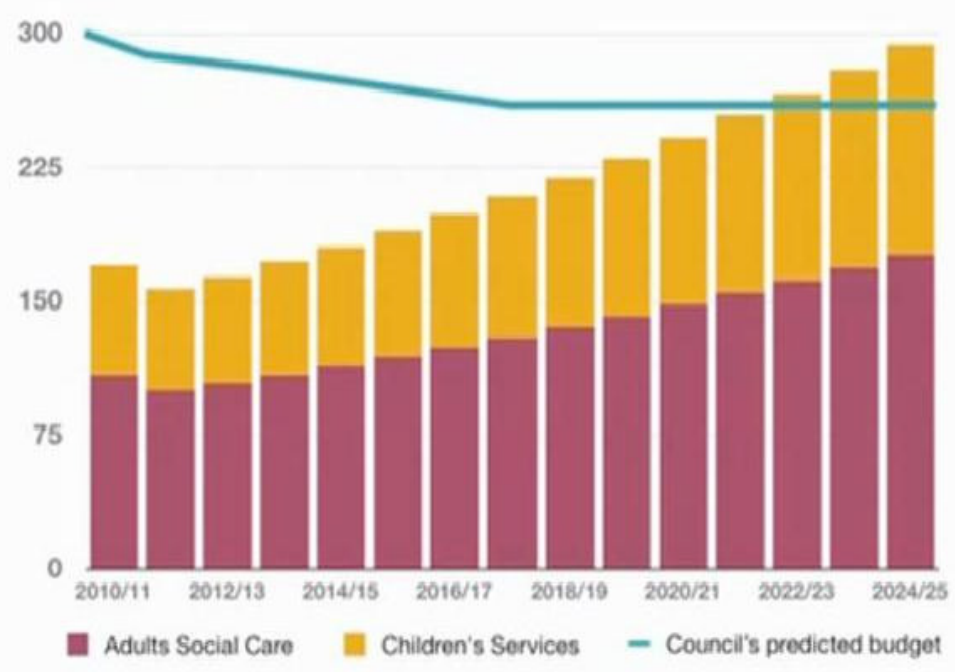

Source: ResearchGate,net

Cuts to public expenditure over the seven years since 2010 have meant that the current position is that the UK is heading for the lowest place on a graph of all the world's major capitalist countries in terms of public spending (Gooby-Taylor 2017).

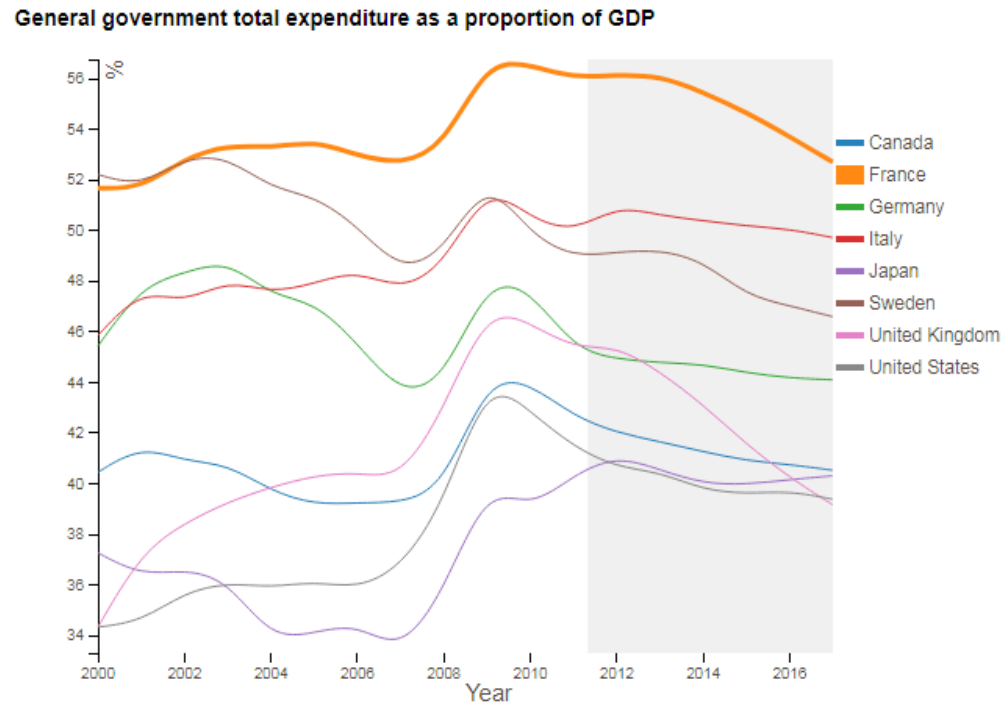

International Monetary Fund World Economic Outlook Database

Actual data to 2011 (USA actual data to 2010) then IMF estimates (darker background).

To what extent this approach is ideological on the part of the Tory-led government in Great Britain is a subject for debate, which is not the focus of this paper. However, 
it is worth noting in this context that the demise of the type of local connections and locally interactive fabric of society that Robert Putnam famously called "social capital" in his 2000 book "Bowling Alone" is now the subject of academic debate. Further, it became a political item when in 2009 David Cameron, Prime Minister at the time, tried to introduce the Big Society to Britain. Essentially, the Big Society idea was that civil society should do more to help itself by using the kind of "social capital" that is the currency of the voluntary sector. Ordinary people and the established Voluntary Sector would take up the delivery of public services where the public sector could no longer provide them, or indeed take over public amenities. It is fair to say that this notion, predicated on the idea that many would volunteer, fell by the wayside and became something of a political embarrassment to the Conservative Party (Woodhouse 2015). Ferragina and Arrigoni (2016) comment that in an age of economic crisis such as that precipitated by the 2008 financial crash,"the policy aim to bolster social capital is incompatible with a neo-liberalist political agenda" (p. 355). Neoliberalism as a political credo sits firmly within the Conservative canon for reducing the welfare state and promoting the predominance of the private sector over the public. It is a curious expectation to ask civil society to demonstrate the altruism typical of the social capital that would support the free exchange of information about community safety in a Conservative-dominated political arena.

In spite of this, partnership, local information and community intelligence are part of the same picture for community policing and for the Fire and Rescue Service with whom the police now work in close collaboration since the advent of the Policing and Crime Act 2017 (Great Britain 2017). This Act brings the emergency services closer together; Police, Fire and Rescue and Ambulance services. It is worth remembering that the Fire and Rescue Services work with and for the community, enjoying longstanding relationships with the localities in which they are sited. As with the Police, links to local areas are strong, and between the two services, a wealth of local knowledge resides. Both services are regular participators in community partnerships such as the LSPs and the CSPs. It therefore remains the case that people working together in multi-agency partnerships, gleaning information from representatives in the local area can help to identify any concerns, even at neighbourhood level, at an early stage. Any losses in terms of the links to this intelligence are worrying, not just to those involved in front line service delivery, but to a national audience. Crawford (in Delpeuch and Ross, 129) suggests in his 2016 analysis that the current Conservative government's narrowing of the police remit to address crime fighting may have resulted in a more generalised lack of police engagement with partnerships and non-statutory participants in community safety. This further distancing of local participation in the partnership 
paradigm may be contributing to the further fragmentation of local intelligence. Coupled with reductions in funding for the Police, this represents an even deeper diminution of resources to support local partnership working.

In a climate, then, of reducing resources and commitment to inter-agency partnership working, plus the blurring of links between PCCs and CSPs, it is small wonder that it has begun to come to the attention of national politicians and those with an interest in the cohesion of civic society that we are losing the links to the local information that could help in detecting and preventing radicalisation and the terrorism that can result from it.

\section{Research origins}

The research for this paper began under the auspices of a research project about multi-agency partnership working in 2016. What emerged from the 2016 research was a concentration on community safety which had not been accounted for in the original research design. The project focused on three partnerships in Sussex and Surrey and sought to produce interim results for a wider research project into partnerships in England. However, it became clear that some of the unexpected material that came to light merited attention, and this focused on community safety issues relating to the role of partnerships in gathering and sharing local intelligence. In addition to the original twelve senior public officials that participated in the 2016 project, a further six community safety and policing personnel have been added to the research in 2017 and 2018.

\section{Research design}

Taking into account the notion of Corporatist Governance and propinquity referred to above, (Pierre 2011, 49) and the fact that the type of partnerships in the research are based in specific geographical areas in local communities, it must be noted that Corporatist Governance tends to focus on urban environments and governance in cities. Some CSPs cover wide rural areas in addition to urban conurbations, so although some aspects of Corporatist Governance are relevant, such as the role of the businesses community in multi-agency partnerships, there are shortcomings in the notion for the purpose of this research. Notwithstanding these shortcomings, John (2008, p. 21 in Pierre 2011,2) points out that the frequency and environmental closeness of contact (propinquity) among partnership members and the duration of 
these relationships are significant factors in efficient governance for these multi-agency partnerships. This feature is reflected in the comments of participants 1-18, who concur that some of the most important elements of a partnership are the duration of the relationships, the trust between members and the speed of transactions (information sharing) within the partnership as a result of these relationships. The final question in each of the 18 interviews was "Can you describe the best thing about the partnership, and the worst thing?". Without exception, participants said that the best thing is the "networking", "relationships between members" and "information sharing". Worst features of the partnership are the processes and procedures, time between meetings and that officer presentations were "too long"(Interviews 6, 7, 8 and 10), eating into networking time.

With regard to theory: the relevance and relationship of Grounded Theory to this research is clear in that the subject matter necessarily demands that focusing on those practitioners who are actually engaged in multi-agency partnership working would be best placed to provide information about local intelligence in the areas in which they operate. Practitioners and senior public officials were selected for interview because of their roles in local multi agency partnerships as either leaders or representatives of organisations. All research participants are currently involved community multi agency partnerships, Community Safety Partnerships or Community Safety matters on a regular, ongoing basis and offer comments from strategic, practitioner and personal viewpoints. They are either local government senior executives, Chief Executives of local authorities and charitable organisations, Police officers and Inspectors. Grounded Theory literally "grounds" the research in practice, and this is the purpose of the research: to investigate the role of multi-agency practitioner partnerships in detecting radicalisation.

The research is based on semi-structured interviews and Non Participant Observation carried out during 2016 to 2018 . These methods were selected in order to provide qualitative information about the partnerships surveyed. A qualitative approach to the research was chosen for its richness and depth, given that the focus for the research is individual actors with a significant role in community safety and a multi-faceted story to tell about their involvement in partnerships and the societal issues that they face. Involvement with communities tends to be deep, taking place on many interactive levels. It is these individuals who puzzle out the complexities of local communities and where to focus attention on issues of concern across the many disciplines and agencies involved in protecting life and safeguarding. 


\section{Findings}

The hypothesis for this research is that local multi agency partnerships such as the CSPs have a significant role to play in detecting radicalisation and helping to prevent the development of terrorist activity through sharing information. Questions investigating the sharing of information were further explored in the interviews undertaken in 2017-18 in order to establish connections with CSPs and the partnership processes for information exchange.

Interviews undertaken for the original 2016 study also included two questions about participants' views concerning what makes the partnership successful, having first asked each participant how they defined partnership success in terms of their professional role. It was these and the final question that elicited information about community safety and the value of the partnership in the early detection of criminal activity and the development of radicalisation in communities. For some, partnership success equated to the number of community "problems" tackled in terms of criminal activity. But what makes the partnerships successful for all but one participant is the ability to share information quickly about problems in the area: to succeed in "troubleshooting" (Interview 9), local problems. 8 responses specifically included the radicalisation of individuals and possible terrorist activity. Six further partnership representatives were then included in the research cohort to take further account of the CSP and policing role in communities and again, what each of the additional participants, without exception, valued most about the partnership was the ability to share information quickly about local individuals and groups, thereby helping to address any problems in the locality.

Furthermore, a key finding from the later research is that it is the formation of long term professional relationships with other practitioners that enables the swifter resolution of local problems for community safety, endorsing the findings from the 2016 results. For example, a Police participant (Interview 17) said"If I have a concern about a family or person in the community that $\mathrm{I}$ believe is involved in radicalisation or other related activity, I can walk across the room where other professionals have come to the partnership and talk to social services, housing, or health professionals about the family to see if they have had any contact with them and what their view is. It's that easy sharing of information that helps me detect pockets of suspect activity so that I can deal with it locally." Among other partnership professionals who participated in this research, 17 affirmed the importance of propinquity and specifically, trusting professional relationships. The findings show that where professionals have evolved relationships of trust in these partnerships, it is the willingness to be open and honest 
in the sharing of information that facilitates co-ordinated action to be taken swiftly to address issues of concern. This is also reflected and supported in O'Neill and McCarthy's 2012 paper (O'Neill and McCarthy 2012). Moreover, what distinguishes the findings in this research is the focus on detecting radicalisation and the importance of co-ordinated, joint action to tackle it in communities.

"Soft skills, hard results" was a comment made by the police officer in Interview 1. By this, the officer meant that investing in the relationships between partners and stakeholders in the community, such as faith groups, charities and community leaders, he was able to achieve multi-layered sets of information about individuals, families and groups. This was later repeated in interviews 17 and 18 when participants were asked about how they built connections with communities. These participants confirmed that their information about those at risk is gained from dialogue with key individuals who are active within those communities. Whilst this is similar to the "social capital" that Putnam $(2000,19)$ refers to, and may indeed be a dimension of it (Putnam 2000, 20) the co-ordinated action it enables distinguish it further from interaction solely for social benefit. The intelligence from local people and multi-agency partners provides key agencies with the means to address problems strategically, planning approaches and responses to achieve the best possible outcome in terms of community safety (Interview 5).

\section{Monitoring and tackling extremism and radicalisation in future}

There are some serious questions to address in tackling extremism and radicalisation in communities, and this paper does not propose replacing any current arrangements in the governance of local areas. Rather it seems clear from the findings in this research project, that instead of side-lining or dismantling local multi agency with an interest in community safety partnerships (Crawford in Delpeuch and Ross 2016), we must strengthen them and use them more efficiently. The role that they play in connecting the local with the national picture of emerging radicalisation and terrorism is one of value in that terrorism, as stated above, is not incubated on a national stage but begins in local communities in neighbourhoods that are known to individuals active in local partnerships, making them more easily accessible through participating local agencies. There are, of course, those individuals that are wholly unknown to the authorities, and no partnership or individual can be omnipresent in detecting covert activity. However, this research shows there is a powerful role for multi-agency partnership in detecting radicalisation and helping to prevent activity that could result in terrorism. Many 
gangs and groups are already known to security services in local areas in the UK, which is a further finding in this research, although not unique. Removing or reducing that stratum of professionals who interact with such groups and pass information to statutory and voluntary agencies who could help tackle the problems associated with them is counter-productive and in some cases could mean that we are less effective in detecting and preventing terrorism, both as a society and as statutory agencies. The loss of these connections to local partnerships and the resourcing reductions that this paper explores have, and will if continued, compromise our joint ability to detect radicalisation in communities.

Because multi agency partnerships are comprised of individuals from a wide range of organisations and groups, it is this resource that provides the conduit for local information to be swiftly and easily passed among agencies. The route for such information is via trusted professional relationships of long standing, and these often exist in local multi-agency partnerships. If such partnerships are compromised or removed, and similarly, if such valuable local resources as PCSOs (Loveday 2017b) are reduced and CSPs side-lined, we diminish our capacity to protect people and society. The, perhaps, unintended consequences of swingeing cuts to local government (Comptroller and Auditor General 2014; Innes and Tetlow 2015; Local Government Association 2015), who participate, manage or lead such partnerships, and cuts to other public sector services in England are that we have less effective, less joined-up networks. This outcome is corroborated in the research for this paper. The more concerning elements of these results are that it is joined up local networks of multiagency groups and partnerships that could help to tackle the emergence of terrorist activity in local areas. Without them we are all more vulnerable.

\section{Interviews:}

Interview 1: Surrey Police.

Interview 2: Surrey Police commander.

Interview 3: Officer from the Police and Crime Commissioners Office, Hampshire. Interview 4: Officer from the Police and Crime Commissioners Office, Sussex.

Interview 5: Former Police and Crime Commissioner.

Interview 6: Leader of a local council in Surrey.

Interview 7: Senior officer, Horsham District Council.

Interview 8: Chief Executive Officer of a District Council in Sussex. 
Interview 9: Retired police officer and councillor in Adur, West Sussex.

Interview 10: Chief Executive Officer for a Surrey Charity.

Interview 11: Elected Member of a Surrey local council.

Interview 12: Former lead officer for Local Strategic Partnership in Worthing West Sussex Interview 13: Former Probation Officer. Sussex.

Interview14: Serving Prison officer. London.

Interview 15: Lead officer for Community Safety Partnership, Hampshire.

Interview 16: Lead officer for Community Safety Partnership, Portsmouth.

Interview 17: Police officer, Hampshire Constabulary.

Interview 18: Community Co-ordinator, Hampshire.

\section{References}

BBC News. 2017. "Question time: Leaders Special with Tim Farron and Nicola Sturgeon." 5 June 2017. https://www.bbc.co.uk/iplayer/episode/b08tj1sg/sign/question-timeleaders-special-with-tim-farron-and-nicola-sturgeon.

BBC News. 19 June 2017. http://www.bbc.co.uk/iplayer/live/bbcnews.

Cheminais, C. 2008. The Origin, Concept and Principles of Multi Agency Partnership Working. Basingstoke: Sage.

Comptroller and Auditor General. 2014. The Impact of Funding Reductions to Local Authorities. London: National Audit Office.

Crawford, A. 2016.'The English and Welsh Experiment in Democratic Governance of Policing through Police and Crime Commissioners: A misconceived venture or a good idea, badly implemented?', in T. Delpeuch and J.E. Ross (eds) Comparing the Democratic Governance of Police Intelligence: New Models of Participation and Expertise in the United States and Europe, pp. 116-52, Cheltenham: Edward Elgar.

Department of the Environment Transport and the Regions (DETR). 2001. Local Strategic Partnerships: Government Guidance 09.

Disney, R. and P. Simpson. 2017. Police Workforce and Funding in England and Wales. IFS Briefing Note BN208, Institute for Fiscal Studies.

Faith Matters. 2017."Open letter to the Prime Minister on countering extremism in partnership with local communities." https://www.faith-matters.org/open-letter-to-the-primeminister-on-countering-extremism-in-partnership-with-local-communities/. 
Ferragina E. and A. Arrigoni. 2016."The Rise and Fall of Social Capital: Requiem for a Theory?" Political Studies Review 15 (3):355-367.

Gooby-Taylor, P. 2017.“UK heading for bottom place on public spending." PSE Poverty and Social Exclusion. http://www.poverty.ac.uk/articles-government-cuts-international-comparisons-public-spending-whats-new/uk-heading-bottom-place.

Great Britain. 1989. “Children Act 1989.” The National Archives. London: HMSO. https:// www.legislation.gov.uk/ukpga/1989/41/contents.

Great Britain. 1998. "Crime and Disorder Act 1998." The National Archives. http://www. legislation.gov.uk/ukpga/1998/37/contents.

Great Britain. 2017. "Policing and Crime Act." The National Archives, retrieved 6 February 2018. http://www.legislation.gov.uk/ukpga/2017/3/contents/enacted.

Great Britain. 2011. "Localism Act 2011." The National Archives. http://www.legislation.gov. uk/ukpga/2011/20/contents/enacted.

Great Britain. 2000. "Local Government Act 2000". The National Archives. https://www. legislation.gov.uk/ukpga/2000/22/contents.

Greig-Midlane, J. 2014. Changing the Beat: The Impact of Austerity on the Neighbourhood Policing Workforce. University of Cardiff. Google Scholar Crossref.

The Independent. 21 June 2017. http://www.independent.co.uk/news/uk/politics/theresamay-police-cuts-budget-finsbury-terror-attack-london-bridge-funding-a7799446.html

Innes, D. and G. Tetlow. 2015. "Sharpest Cuts to Local Government Spending in Poorest Areas: same areas likely to lose most in next few years." Institute for Fiscal Studies. https:// www.ifs.org.uk/publications/7621.

Joseph Rowntree Foundation (JRF). 2015. https://www.jrf.org.uk/press/ most-deprived-areas-have-borne-brunt-local-government-budget-cuts.

Ling, T. 2002. "Delivering Joined Up Government in the UK: Dimensions, Issues and Problems." Public Administration 80(4): 615-642. Blackwell, Oxford.

Local Government Association (LGA). 2015. Future Funding Outlook for Councils 2019/20: Interim 2015 Update. London: Local Government Association.

Local Government Association (LGA), Lord Gary Porter. 2017. "LGA responds to Local Government Finance Settlement." https://www.local.gov.uk/about/news/ lga-responds-final-local-government-finance-settlement

Loveday, B. 2013. "Police and Crime Commissioners: the changing landscape of police governance in England and Wales: their potential impact on local accountability, police service delivery and community safety." International Journal of Police Science and Management 15(1): 22-27. 
Loveday, B. 2017a. "The governance of the police and current challenges to police service delivery in England and Wales." American Police Foundation Journal, Washington DC. (Forthcoming).

Loveday, B. 2017b. "Still Plodding Along? The Police Response to the Changing Profile of Crime in England and Wales." International Journal of Police Science and Management 19(2):101-109.

O'Neill, M. and D. McCarthy. 2012. "(Re)Negotiating police culture through partnership working: Trust, compromise and the "new" pragmatism." Criminology and Criminal Justice 14(2): 143-159.

Pierre, J. 2011. The Politics of Urban Governance. Basingstoke: Palgrave Macmillan.

Pollitt, C. 2003."Joined up Government: A Survey." Political Studies Review 1: 34-49.

Putnam, R. 2000. Bowling Alone. New York: Simon and Schuster.

Rees, J., D. Mullins, and T. Bovaird. 2012. Partnership Working. Research Report 88. Third Sector Research Centre.

Sawyer, M. 2011. "The tragedy of UK fiscal policy in the aftermath of the financial crisis." University of Leeds. Retrieved 6 February 2018 https://www.boeckler.de/ pdf/v_2011_10_27_sawyer.pdf

UNISON. 2016. "The Future of our Police." https://www.unison.org.uk/news/ article/2016/04/the-future-of-our-police/ Retrieved 15 June 2017.

Woodhouse, J. 2015. Briefing Paper Number 5883: The Voluntary Sector and the Big Society. London: House of Commons. 